\title{
brazilianpoliticalsciencereview
}

B OOK R E V I E W

\section{Still the Country of the Future*}

\author{
by Octavio Luiz Motta Ferraz ${ }^{\dagger}$
}

${ }^{\dagger}$ King’s College, London, United Kingdom

(Lavinas, Lena. The Takeover of Social Policy by Financialization: The Brazilian Paradox. New York: Palgrave Macmillan, 2017)

Has Brazil made significant social progress during the longest left-wing democratic government in its history, the Workers' Party (PT, Partido dos Trabalhadores) rule from 2002 to 2016 ?

This is an immensely complex question whose answer depends in great part, of course, on the criteria of social progress adopted, which is in turn a contested issue. But there seems to be a strong consensus that, at least in one dimension, i.e. the reduction of poverty, Brazil made substantial progress in the PT years, as tens of millions of people were raised above the poverty line during that period.

But the consensus stops there. When we move from extreme poverty to broader issues such as inequality and the population's well-being, agreement is much thinner. The celebrated decrease in economic inequality lauded both domestically and abroad, for instance, has been put into question by recent research based on tax data unavailable to earlier studies (MEDEIROS et al., 2015). The improvements in health, education, and race and gender equality are also a matter of ongoing debate ${ }^{1}$.

Lena Lavinas' (2017) recent book, "The Takeover of Social Policy by Financialization: the Brazilian Paradox", is an important contribution to this debate. She is fiercely critical of the impact of the PT's rule in that period. The self-proclaimed center-left government failed, in her view, to make progress beyond the important, but nonetheless limited achievements of the conditional cash transfer programme (Bolsa Família). It missed the opportunity to "transform social relations and blunt the privileges of the

(*) DOI: http://dx.doi.org/10.1590/1981-3821201800030009

This publication is registered under a CC-BY Licence.

${ }^{1}$ For a comprehensive and longer term analysis that goes well beyond income inequality, see Arretche (2015). 
better-off" (LAVINAS, 2017, p. 177). It failed to consolidate the social protection system laid out by the 1988 Constitution, which is based on universalism and solidarity.

The paradox is in the fact that this failure, according to Lavinas (2017), should be, by and large, attributed to the PT's own policy choices, and not to external political and economic obstacles and forces that tend to blunt left-wing attempts at radical reform. As she strongly puts it in the concluding chapter:

It is undeniable that redistribution was never made a priority under the tenure of the Workers' Party. It was not just that there was no room for a thorough courageous tax reform that might have tackled the regressivity of the prevailing system. Rather, tax policies and tax regulations were honed to serve the logic of financialization through an active thrust toward more exemptions and tax credits in favour of businesses and rich households, concentrating wealth and power against the grain of the collective interest (LAVINAS, 2017, p. 176).

Coming from a respected academic with a long-standing history of association with progressive movements, including the PT itself, the indictment is all the more powerful and calls for serious engagement and scrutiny from all those interested in development and social policies in Brazil2.

\section{What went wrong?}

The main cause of this failure - or worse: this retrogression, in Lavinas' view (2017) - is the creeping financialization of social policy, as reflected in the book's title. By financialization she means "an array of empirical features and processes... of a new accumulation regime in which macroeconomics and economic policies are increasingly dominated by the rationale of financial capital" (LAVINAS, 2017, p. 07). The influence of financialization, she stresses, is not only felt in the market place, with the predominance of financial markets and transactions over production and trade and the tendency for profits to occur in financial markets rather than in productive activity, which results in the increase of the economic and political power of a rentier class. It pervades all realms of social life and, as a consequence, it should come as no surprise to see it affecting social policy as well. What is indeed surprising is that a government of the left would not only fail to resist financialization but actually embrace and boost it as the PT has done, according to her analysis.

These notable changes in social policies were not, Lavinas argues (2017), a haphazard and fragmented occurrence, but rather part of a broader model of development deliberately adopted by the PT government, dubbed "social developmentalism" or "redistributive devel-

\footnotetext{
${ }^{2}$ Lena Lavinas was a member of the PT until the 1990s and worked in the PT's municipal government of Nova Iguaçu from 2006 to 2010.
} 
opmentalism guided by the state", which bet heavily on the expansion of a mass consumption society. Her argument is that this model had biases and limitations which occluded the logics and dynamics of financialization. The complementarity between this model of development and the "financialized" social policies ended up failing to lead "Brazil into the post-war Golden Age, consolidating the welfare state" (LAVINAS, 2017, p. 05). As a consequence of this lost opportunity, "staggering inequalities remain the calling card" of Brazil and the search for a future "as a nation of all and for all" remains elusive.

The breadth of social policy issues Lavinas (2017) discusses to substantiate her claim is impressive, ranging from pensions and anti-poverty assistance programmes to health and education. She also provides data and analysis of tax exemptions and deductions, consumer credit and debt which are essential for a better understanding of what she claims represented a "profound and radical transformation of the logic, ends, and making of social policy" under the auspices of the PT. In her view, social policy moved away "from rights-based decommodified benefits and toward further commodification" (LAVINAS, 2017, p. 11).

In order to probe the strength of Lavinas' claims (2017) it is necessary to delve into the extremely rich and complex details of her arguments. This is of course not possible within the limited space of a book review. But I hope the following few pages will be sufficient to give the reader an accurate summary of how the argument develops in some of the main social policy areas discussed in the book and where, in my view, it is somewhat lacking or could be more robustly defended. As will become clear, I agree with Lavinas that the PT years were much less transformative than they are often perceived to have been. Where I have some doubts, however, is on the actual magnitude and causal determinants of this failure.

\section{Social Policies in the PT years}

\section{Health}

Despite the universalistic and egalitarian principles enshrined in the 1988 Constitution, the fact is that the public health system has never been truly comprehensive (in great part due to underfinancing, with only about $04 \%$ of GDP being spent on public health) nor genuinely universal, in the sense of the whole population actually using it. On the one hand, the middle classes, who since the military period had already started to desert the public system in favour of private health plans and insurance, were never brought back into it; they continued to use private services, receiving sizeable tax incentives to do so. On the other hand, even those who cannot afford private insurance and thus rely exclusively on the public system still have to spend considerable amounts "out of pocket" to acquire benefits not covered by the public system, such as medicines. 
Thus, despite the constitutional rhetoric, the Brazilian state itself fosters a dual system where most of the population is insufficiently covered by an underfinanced public system whereas about one quarter has access to a more comprehensive and tax subsidised private system. The paradoxical fact is that, although this framework did not start during the PT government, it was actually extended during that period, when "successive laws were shaped in order to create fiscal incentives for development and to strengthen private healthcare plans and policies, expanding tax deductions for households and service providers" (LAVINAS, 2017, p. 136).

This is reflected in the magnitude of tax incentives to private health care (technically called "tax expenditure" on health), which reached astounding levels during the period. If one looks only at income tax deductions for individuals, it reached "10\% of the federal spending" on health in 2014 (from 2007 to 2014, the aggregate value was R $\$ 86.6$ billion [US\$22.4 billion]). When one adds all the deductions made by companies, plus the tax exemptions given to the pharmaceutical industry and philanthropic hospitals, as proposed by Ocké-Reis and Gama, it reaches "30\% of federal expenditure on health" (OCKÉ- REIS and GAMA, 2016).

Perhaps the most surprising of all policies was the rebate introduced in 2006, through Law 11.302, to assist public servants in paying for private insurance premiums. The Brazilian "universal" public system is therefore not used even by public servants, who are doubly incentivised to opt out of it via income tax deductions and direct payroll rebates.

Private healthcare companies have exploited these opportunities well by selling cheaper plans with lower coverage, which accounted in 2013 for $57.6 \%$ of the market (considering the two cheapest plans, below R $\$ 199$ or US\$92.10 per month [LAVINAS, 2017, p. 137]). The tragedy of this trend, where poor people also try to leave the public system, is not only in the consequences this has for the spirit of universality. It also pushes the poor into more debt as, according to Lavinas (pp. 142-143) some of the beneficiaries of these plans make use of consigned credit (another plank of financialization which we will discuss below) in order to buy private health care.

So, whereas federal public expenditure on health remained fairly constant under the PT rule, at around $1.7 \%$ of $\mathrm{GDP}^{3}$, private health saw a remarkable growth, with the market value of companies achieving R $\$ 40.4$ billion (US $\$ 10.439$ billion) in 2015 , from just $\mathrm{R} \$ 12.2$ billion (US $\$ 3.152$ billion) in 2002. Other business-friendly legislation and regulation during that period included generous concessions of philanthropic status certificates to private companies in the health sector and opening the system to foreign investment in 2015 (Law $13.097 / 2015)$.

\footnotetext{
${ }^{3}$ It is important to clarify that the majority of public health spending in Brazil comes now from states and municipalities, reaching around $04 \%$ of GDP, as mentioned above.
} 
Lavinas (2017) seems right to claim, therefore, that the Brazilian public health system is "enfeebled by lack of financing and heavily stratified to boot" (LAVINAS, 2017, p. 136), resembling more the American Medicaid (healthcare for the poor) than a genuinely universal system, and that the PT governments did not reverse this situation. Is she correct, though, in laying the blame squarely on the PT's deliberate policies? It is always hard, of course, to determine what the exact responsibility of a political party is on any issue in pluralist systems, especially when they are extremely fragmented as in Brazil. But Lavinas (2017) unrelenting critique seems a little overdrawn here in light of complex political battles not discussed in her book, such as the termination by Congress in 2007 of the tax (contribution) that provided important resources for health care (the CPMF), and its rejection of a new tax to help fund health care in 2011 (the Contribuição Social da Saúde, CSS), both against the PT’s position.

Even the government's rebate to help public servants buy private health insurance seems to need further discussion. As Lavinas (2017) correctly points out, it was introduced via article 09 of Law 11.302 of 2006, that is, in the last year of Luiz Inácio Lula da Silva's first term in power. But Lula's original bill, Provisory Measure 275 of 2005, did not include this article. The original bill was all about increases in the remuneration of the medical experts of the National Institute of Social Security (INSS). So how did the rebate end up in the final bill, which passed as Law 11.302? What would have been important, in order to support the book's argument, would be to demonstrate that the inclusion of the rebate was a deliberate policy choice of the PT and not, for instance, something that the lobby for private health insurance in Congress managed to "negotiate" into the original bill.

\section{Education}

Like health care, education in Brazil is also highly stratified and the private sector also started to flourish many years ago, under the military regime. At the university level, however, public institutions are still by and large more prestigious and better ranked than private ones, leading to another Brazilian paradox highlighted by Lavinas: "middle-class, upper-middleclass, and wealthy children and teenagers tend to study in high-quality, expensive, and selective private schools, and then turn to the public system when they enter college" whereas "low-income and working-class youths ... swell the ranks of public schools ... and are later left to try their luck in private universities, aided by scholarships and educational credit" (LAVINAS, 2017, p. 146).

Here she acknowledges that some important initiatives were taken under the PT's rule to democratize access to higher education, such as the creation of 14 new federal universities between 2003 and 2014, the launch of REUNI in 2007, the passing of the Quotas Law in 2012 that reserves $50 \%$ of places in federal universities to applicants who attended public 
secondary education. These policies have diminished the gap between the poor and the rich in terms of access (e.g. 45.5\% of 'blacks and browns' now attend university as opposed to only $16.7 \%$ in 2004).

As she pointedly notes, however, these initiatives have been insufficient to keep up with demand, and the "solution" was once again to be found in the private sector, through scholarships, subsidised loans and tax incentives for corporations to provide educational services to those unable to access public universities. From 2005 to 2014, 873.600 students were granted full scholarships and another 400.000 received partial aid through PROUNI. Aggregate taxes waived through this policy added up to $\mathrm{R} \$ 3.257$ billion (US\$ 1.567 billion) from 2005 to 2012. The policy of subsidised loans had already started in 2001, during the Cardoso government, through the Student Financing Fund (Fundo de Financiamento Estudantil, FIES), and Lula kept it unchanged until 2009. In 2010, however, important changes were introduced to transform the programme into the "major channel for supporting the expansion of private-sector supply" (LAVINAS, 2017, p. 148). Interest rates were cut to $3.4 \%$ and the repayment period extended to three times the length of the degree plus one year. This provided a boom to the private sector, leading to a wave of acquisitions and mergers among the largest educational corporations and growth at breakneck speed. To illustrate this, she recalls that Kroton S.A. was in 2013 the largest private education group in the world, with a market value of RS $\$ 27.6$ billion (US\$9.8 billion).

In Lavinas view (2017), this process of concentration and financialization completely transformed the educational sector, once conceived as based on "citizenship rights". In 2014, federal government spending on higher education was RS\$ 34 billion (US\$ 14,4 billion), of which FIES consumed no less than RS $\$ 14$ billion (US $\$ 6.4$ billion), i.e. over $40 \%$ of the total (LAVINAS, 2017, p. 151). One may be tempted to see FIES in a positive light, as an efficient and pragmatic way of extending access to higher education to previously excluded groups. As Lavinas (2017) emphasises, however, this is potentially not as efficient as it seems. Private educational institutions have been increasing their tuition fees above inflation, thus using FIES as an opportunity to raise their profits, with the consequence that student debt has also increased substantially, as has default in FIES's loans, which stood at 47.14\% in 2014.

\section{The pension system}

In a way similar to health and education, the private pension sector also saw a remarkable growth during the PT years. As Lavinas reports (2017), the aggregate asset value of private pension funds grew from a relatively meagre R $\$ 23$ billion (US\$ 5.9 billion) in 2002 to almost R $\$ 500$ billion in 2015 (US $\$ 130$ billion). To enable comparison, the amount collected in contributions by the "pay as you go" state system in 2017 was $\mathrm{R} \$ 374,8$ billion. 
Again, this growing privatization of pensions did not start in the PT years, yet it was not reversed, but rather incentivised during that period, claims Lavinas. One important incentive, she points out, was the extension of the cap introduced during Cardoso's government (currently at $\mathrm{R} \$ 5.189,00$ ), from the pension system of private workers (RGPS) to that of public servants (RPPS), with the exception of military personnel.

But Lavinas (2017) arguments here seem less straightforward than those regarding health and education. On the one hand, she denounces the weakening of the logic of "intergenerational solidarity, shifting revenue (from the richest, it should be stressed) to the private insurance market that should have been channelled into the public system" (LAVINAS, 2017, p. 121). She claims that this is because the low level of the benefits cap in the "pay as you go" state system introduces competition with the private system and "sucks funds away to the financial sphere". On the other hand, she herself also states that the PT reforms "radically transformed" pensions in the public system, "striking a definitive blow [with the exception of military personnel] to the still-common perception that retirement plans for civil servants in Brazil concentrate and reproduce privileges and inequalities" (LAVINAS, 2017, p. 122).

It is not very clear if Lavinas (2017) believes that the two can be reconciled and how; in other words, at what level should the cap be set, or what other changes ought to be made, so as to keep the public system fair and sustainable at the same time. At a juncture when reform of the pension system is the order of the day, such discussion seems to be of the utmost urgency.

\section{Tax breaks and exemptions}

Another important plank of Lavinas (2017) argument is that tax breaks for businesses and the better off were "a major instrument of industrial policy while [Lula] was in office" (LAVINAS, 2017, p. 114) but also during Dilma Rousseff's terms. There were major exemptions to COFINS, PIS-PASEP, and CLSS, and also to employers' payroll contributions. These are all taxes (or "contributions", in technical terms) that feed into the budget of the social security system. These tax breaks were supposedly an instrument of industrial policy, aimed at improving economic activity and competitiveness in a few areas affected by high exchange rates and international competition, and at improving employment and jobs as a result. Yet, argues Lavinas (2017), they were extended indiscriminately to no less than 56 sectors without any conditionalities or targets and ended up not achieving their original goals.

The numbers reported by Lavinas (2017) from the studies by Carolina Cordilha and Denise Gentil are staggering. According to the latter, tax breaks between 2007 and 2015 amounted to R $\$ 1.9$ trillion (US $\$ 500$ billion), depriving the social security budget of R $\$ 872$ billion (US $\$ 225.3$ billion), or $130 \%$ of all social security spending for 2015 . Adding to this siphoning off of social security revenue, the so-called "Untying of Federal Revenue" (Desvin- 
culação de Receitas da União - DRU), which allows the Federal Government to spend freely (i.e. in other areas) a large percentage of the social security budget, removed a further $\mathrm{R} \$ 743.3$ billion (US\$ 193.1 billion) from its budget from 2005 to 2015.

The outcome was, in her view, "serious consequences for the Social Security Budget that would ultimately compromise the financing of social policies", health care and social assistance in particular, and an artificial worsening of the budget of the state pensions system (LAVINAS, 2017, pp. 114-115).

\section{Poverty, the "new middle-class" and debt}

Another important contribution of the book resides in Lavinas (2017) challenges to some of the received wisdoms about social policy in Brazil during the PT rule. A standard view, even among detractors of the PT, is that it presided over a period that witnessed the greatest reduction of poverty Brazil has ever seen. Lavinas (2017) does not deny these advancements. As she makes clear, "it is true that the poorest sectors of Brazilian society saw a considerable improvement in their condition..." (LAVINAS, 2017, p. 28). But she puts these achievements into sharp perspective, questions their actual determinants and their future sustainability. With recent data showing an increase in unemployment, poverty and even infant mortality since she wrote the book, her arguments seem even more credible.

As for the creation of 20 million posts in the formal job market, she reminds us that most of these jobs "were low remuneration ... and low productivity posts" (LAVINAS, 2017, p. 128), which explains the high turnover in that sector, along with the surprising growth of spending on unemployment insurance during that period (from R $\$ 21.3$ billion (US $\$ 5.5$ billion) in 2005 to $\mathrm{R} \$ 61.4$ billion (US $\$ 15.9$ billion) in 2014). As for the internationally acclaimed Bolsa Família programme, she notes that it consumes less than 0,5\% of GDP, is targeted, conditional and meagre, that is, in total contradiction with the universal and egalitarian rhetoric of social assistance in the constitution: a "non-right" that exacerbates horizontal inequities; "a discretionary measure ... reinforcing means-tested minimums, at the price of a Social Security system bereft of its structural principles and values" (LAVINAS, 2017, p. 131).

Moreover, and going against the grain of most commentators, she highlights the role of the explosion of consumer credit (and debt, as a consequence) and the creation of a myriad of financial products and services for the poor ("financial inclusion" via consumer and microcredit) as the "factor of greatest significance" in the expansion of consumption and the domestic market, and not simply the often quoted boost in household income by formal employment and rises in the minimum wage (LAVINAS, 2017, pp. 38 and 52).

This further exemplifies a major change in the political philosophy underpinning social policies, from "public welfare schemes toward the provision of well-being through private 
sector and financial markets" (LAVINAS, 2017, p. 41). It is also unsustainable and the consequences can be disastrous. In a recessive situation, as we have seen in the past couple of years, it can hamper the resumption of economic activity and it threatens the well-being of families, making them more dependent on the financial system (LAVINAS, 2017, pp. 55-56).

This is linked to another myth that Lavinas problematizes (2017) in the book, namely the rise of the so-called "new middle class". As she aptly observes, although from a purely statistical perspective the numbers of those in the middle of the income spectrum clearly expanded during the PT rule, between 22 to 29 million depending on the criteria adopted, if one takes a more complex perspective, including class identity, social homogenization, and breaking down of material and symbolic barriers (LAVINAS, 2017, p. 84), it seems clear that no such a group emerged in Brazil. This may explain the lack of a "middle class consensus", and presents an important obstacle to "the construction of a robust political coalition which might have been able to promote substantive change in the productive structure and social make up of Brazilian society" (LAVINAS, 2017, p. 85).

\section{But how far away is the future, and what is actually delaying it?}

Lavinas' book (2017) provides a comprehensive and detailed account of the PT's record on social policies in their 14 years of tenure in government. It enlightens those unfamiliar with the details of social policies of that period and raises robust challenges to those who hold a positive view of that record. These two achievements are impressive in themselves and make her book a must read for both audiences. The book also provides plenty of evidence that the dreamed-of future of "a nation of all and for all" (LAVINAS, 2017, p. 11) remains very far away. One may be left wondering at the end of Lavinas important contribution, however, whether her implacable criticism of the PT's record is not somewhat overemphasized and its achievements downplayed.

Take for instance her criticism of the revenue restrictions of the Social Security budget due to tax breaks and exemptions. Lavinas (2017) herself admits that it is surprising that social security expenditure actually also rose between 2005 and 2015, from 10\% of GDP in 2005 to $11.57 \%$ in 2015 . It seems also somewhat unclear how this can be reconciled with the conclusion that the revenue restrictions had "serious consequences for the Social Security Budget that would ultimately compromise the financing of social policies" (LAVINAS, 2017, p. 114-115). As Lavinas (2017) herself also reports, expenditure on the public health system remained steady over time, at $1.7 \%$ of GDP, and expenditure on unemployment insurance and poverty-fighting programmes expanded as a proportion of GDP, practically doubling in size (LAVINAS, 2017, p. 117-118). In the field of education, although the criticism of PROUNI is well made, the achievements attained by the Quotas Law, the REUNI and the creation of 14 
new federal universities are not easily dismissed.

It is true, as Lavinas notes (2017) accurately, that such improvements fall very short of what would be necessary to truly consolidate the 1988 Constitution's progressive egalitarian project. Moreover, many of the policies implemented during the PT's rule, as she painstakingly shows, were certainly incompatible with that ideal and thus paradoxical for a progressive party to adopt. But it seems at least questionable whether they amount to the significant retrogression that Lavinas (2017) sees. Perhaps a more measured conclusion would have been that the PT years were disappointing in light of what one might have expected from a progressive government. There seems to be something here of what Marta Arretche (2015) refers to as "moving metrics" in her more optimistic assessment of the changes that took place in Brazil in the past 50 years, that is, the fact that "more demanding aspirations are adopted as progress occurs" (ARRETCHE, 2015, p. 426). Psychologist Steven Pinker (2018) also discusses this in his most recent book "Enlightenment Now" and suggests that most of us have a bias that makes us focus on bad things more, rather than on how much they have improved in reference to the past ("Bad is stronger than good", PINKER, 2018, p. 47).

The reader may also be left wondering about a fundamental question that receives less attention in the book than it perhaps deserves, namely the explanation for the paradox so well described and substantiated in the book. Why, after all, did the PT not only fail to radically transform Brazil but also adopted some policies that went in the opposite direction? Did it lack courage and boldness? Was there real political space for a more radical and progressive project? Did it sell out? These are of course complex questions that analysts will keep debating for a long time. Given Lavinas (2017) invaluable exposition of the paradox, her insights into its potential explanation would have made her book even better.

Revised by Priscilla Kreitlon

\section{References}

ARRETCHE, Marta (ed) (2015), Trajetórias das desigualdades: como o Brasil mudou nos últimos cinquenta anos. São Paulo: Editora Unesp. 489 pp..

MEDEIROS, Marcelo; SOUZA, Pedro H. G. Ferreira de, andCASTRO, Fábio Avila de(2015), 0 topo da distribuição de renda no Brasil: primeiras estimativas com dados tributários e comparação com pesquisas domiciliares (2006-2012). Dados. Vol. 58, № 01, pp. 07-36.

OCKÉ-REIS, Carlos Octávio and GAMA, Filipe Nogueira da (2016), Nota técnica: radiografia do gasto tributário em saúde 2003-2013. São Paulo: Ipea. 35 pp.. 
PINKER, Steven (2018), Enlightenment now: the case for reason, science, humanism and progress. New York: Penguin Random House LLC. 576 pp.. 